\title{
Prioritization of Contracting Methods for Water and Wastewater Projects Using the Fuzzy Analytic Hierarchy Process Method
}

\author{
Hadi Sarvari $^{1, * \mathbb{D}}$, Daniel W. M. Chan ${ }^{2} \mathbb{D}$, Behrouz Ashrafi ${ }^{1}$, Timothy O. Olawumi ${ }^{3}$ and Nerija Banaitiene ${ }^{4, * \mathbb{D}}$ \\ 1 Department of Civil Engineering, Isfahan (Khorasgan) Branch, Islamic Azad University, \\ Isfahan 81551-39998, Iran; b.ashrafi@khuisf.ac.ir \\ 2 Department of Building and Real Estate, The Hong Kong Polytechnic University, Hung Hom, Kowloon, \\ Hong Kong, China; daniel.w.m.chan@polyu.edu.hk \\ 3 School of Engineering and Built Environment, Edinburgh Napier University, Edinburgh EH10 5DT, UK; \\ t.olawumi@napier.ac.uk \\ 4 Department of Construction Management and Real Estate, Vilnius Gediminas Technical University, \\ Sauletekio al. 11, 10223 Vilnius, Lithuania \\ * Correspondence: h.sarvari@khuisf.ac.ir (H.S.); nerija.banaitiene@vilniustech.lt (N.B.)
}

Citation: Sarvari, H.; Chan, D.W.M.;

Ashrafi, B.; Olawumi, T.O.;

Banaitiene, N. Prioritization of

Contracting Methods for Water and Wastewater Projects Using the Fuzzy Analytic Hierarchy Process Method Energies 2021, 14, 7815. https:// doi.org/10.3390/en14227815

Academic Editor: Anastasios Dounis

Received: 30 September 2021 Accepted: 16 November 2021 Published: 22 November 2021

Publisher's Note: MDPI stays neutral with regard to jurisdictional claims in published maps and institutional affiliations.

Copyright: (c) 2021 by the authors. Licensee MDPI, Basel, Switzerland. This article is an open access article distributed under the terms and conditions of the Creative Commons Attribution (CC BY) license (https:// creativecommons.org/licenses/by/ $4.0 /)$.

\begin{abstract}
This study uses the fuzzy analytical hierarchy process (FAHP) method to prioritize contracting methods to determine the most suitable contract option for water and wastewater projects (WWP). Content analysis, a two-round Delphi survey technique, and a series of validation and reliability tests helped establish the 18 key criteria for FAHP analysis. Consequently, data collected from experts through a pairwise comparison questionnaire form the basis for the inputs for the FAHP analysis. Consequently, the final weightings were derived for each of the key criteria and available contracting methods. The results indicate that the bilateral, cooperative, and trilateral contracting methods are the most suitable for WWP in Iran, with the highest weighting. The study provides useful guidance for the top management of project firms in selecting the optimal contracting method for their projects and offers significant contributions from theoretical and practical perspectives.
\end{abstract}

Keywords: fuzzy analytic hierarchy process; construction contract; water; wastewater; Iran

\section{Introduction}

The development of infrastructure projects in the water and wastewater industry is one of the essential sectors for developing countries to achieve sustainable development [1]. The main characteristics that distinguish these projects from other types of projects include considerable financial needs, a high level of science and technology, the need for extensive technical knowledge, a high workload, and the time-consuming nature of these projects [2]. Therefore, considering these features, it is imperative to choose the appropriate method to provide and implement this category of projects, and making a mistake in this regard will cause irreparable costs and losses.

The selection of the type of contract is one of the most critical decisions in any project [3], as it plays a vital role in the ultimate success of the project [4]. Poor choice can lead to confusion and misunderstandings among key personnel and increase the chances of failure [5]. Various types of contracts are designed for use in different projects; therefore, factors and criteria specific to the project must be considered when selecting the appropriate contract method for projects. A precise and appropriate selection of the type of contract can help counterbalance the risks of the project, making it one of the most important decisions in any project [6,7]. Therefore, adopting an appropriate policy in the decision-making process regarding development projects is critical, and the development of support systems and tools for decision-making can be of great help to implementers. There are many factors that contracting parties should consider when selecting the type of contract. Emerging global environmental problems force us to evaluate a contract for the 
water and wastewater project (WWP) not only in terms of price and quality. Wastewater treatment processes, such as effluent discharge and indirect emissions resulting from energy or chemical production, also negatively affect the environment [8]. The treatment of water and wastewater must become functional, appropriate, and sustainable $[9,10]$. Treatment of wastewater is an important part of the water cycle that allows sanitation and reuse of water, facilitates energy generation, and allows the recovery of waste products [11,12]. Sustainable wastewater treatment is a viable option to address the challenges of energy shortage, resource depletion, and environmental pollution [13]. The application of multi-criteria decision-making (MCDM) tools could help decision-makers consider the sustainability, affordability, reliability, and functionality of water and wastewater systems [14-17].

Construction projects are often carried out in a complex and uncertain environment where different stakeholders have different priorities and perceptions. Hence, previous studies have adopted some multi-criteria decision-making techniques to aid project teams with their decision-making processes. For example, Camci and Çimen [18] for the selection of the most appropriate construction contract type used a spherical fuzzy analytic hierarchy process (AHP) method. The spherical fuzzy version of AHP was chosen because it can comprehensively address the hesitancy hidden in the preferences of decision-makers. Taylan et al. [19] integrated contractor selection approaches for the formulation of decision problems using fuzzy and crisp data. The fuzzy AHP approach was used to determine the weights of the criteria and the fuzzy TOPSIS method was used to assess the contractor's performance.

Project risk management has a significant impact on project performance because the identification and handling of uncertainties increases productivity in terms of cost, time, scope, and quality. Faraji et al. [20] introduced a novel approach to solve the contract selection problem in the context of drilling projects. Consequently, a generic list of prospective risks was structured and a risk-BWM based model was proposed to solve the original problem of contract selection.

The duration of the project, the total cost of the project, and the quality of performance are considered one of the main factors that affect the choice of contract methods by clients and contractors in construction projects [21-23]. Budayan et al. [24] identified and prioritized key performance indicators (KPIs) that can be used to evaluate the performance of build-operate-transfer (BOT) projects using the Technique for Preference by Similarity to Ideal Solution (TOPSIS). Similarly, quality-related KPIs were determined to be among the most important KPIs in this study.

To ensure that the construction project will be completed successfully in terms of the scope, time, cost, and quality of the project, the client must select the most appropriate contractor. According to Sarvari et al. [25], capabilities such as new technologies, the use of previous experiences, knowledgeable teams, and the selection of suitable contractors are among the most important success factors in construction projects. Marović et al. [26] proposed a decision support concept to select the optimal contractor. The proposed concept is based on the synergistic effect of the AHP and PROMETHEE methods, each applied at different stages of the procurement procedure. Different types of criteria were ranked, but from the client's point of view, the three most important criteria were defined as costs throughout the life cycle, quality, and price of the offer. Oyatoye and Odulana [27] proposed a prototype system for the selection of contractors based on the AHP methodology. This decision support tool can help the decision-maker in selecting the most qualified contractor.

According to Hosseini et al. [18], the use of the appropriate project delivery method is one of the key factors in achieving project objectives and project success. Culp [28] compared traditional and alternative project delivery methods in terms of their effects on quality, schedule, and costs in water and wastewater treatment projects. Project delivery methods such as traditional design-bid-build (DBB) and alternative project delivery methods of design-build (DB), design-build-operate (DBO), and design-build-finance-operate (DBFO) were discussed. Finally, conclusions were reached that alternative project delivery methods can save time and money while providing equal or superior project quality when 
applied appropriately to water and wastewater treatment projects. Godfrey et al. [29] analyzed various contractual arrangements to improve the functionality of urban water services in Ethiopia. Therefore, the differences and rationale of the build-capacity buildtransfer (BCBT) and the build-operate-transfer (BOT) contractual agreements were outlined. To assess the effectiveness of BCBT, the fuzzy logic concept was applied. The results revealed that BCBT is an effective contracting modality that should be accompanied by appropriate behavior change and social mobilization outreach to maximize the extension and performance of water supply systems. Roustaei [30] examined the design and build contracts to be adopted by a Tabriz water and wastewater company using the AHP method. The build-own-operate (BOO) contract received the lowest priority. On the contrary, other alternatives, such as the design-build-operate-transfer (DBOT), build-own-operate-transfer (BOOT), and build-operate-transfer (BOT) contracts, were prioritized in descending order.

Various multi-criteria decision analysis (MCDA) methods are proposed and adopted by researchers to support contracting decisions. Given the above review of the existing literature, it is evident that previous studies are limited to identifying and investigating project success factors, and it is evident that the selection of the appropriate contract method is critical to the success of any project. Therefore, the current study aims to develop a contract selection model to help decision-makers determine the most suitable contract methods for WWP. In addition, in the study, an advanced MCDM technique (the FAHP method) was adopted.

Water and wastewater companies in Iran often use the trilateral approach to contract. Therefore, to achieve the aim of the study, the criteria that affect the selection of the contract for water and wastewater projects were identified from the existing literature [30-34]. Furthermore, the Delphi technique [35-37] was used to define and match the identified criteria based on existing literature in the Iranian context. Finally, the FAHP method was applied to the identified criteria, which were categorized into five different groups, and to rank the four types of contracts used for WWP in Iran.

\section{Contracting Methods for Projects}

Each type of contract has distinct benefits and drawbacks, and the best choice is governed by the specific requirements of the project. Identifying the appropriate contract criteria that have a favorable influence on the successful implementation and completion of wastewater collection and disposal projects is critical to help project decision makers, such as clients and contractors [30]. Various studies have been conducted in this regard, the content of which clarifies the current contract methods used in infrastructure projects. For example, Roustaei [30] conducted a study to identify, categorize, and suggest the best possible methods to select initial documents without ambiguity and to reduce cost and project time by investigating urban wastewater projects in Iran. The study suggested a contract method for these projects by interviewing managers and other executive partners involved in urban wastewater projects and employing an applied approach, based on the objectives of the study. Twelve projects were investigated for a total value of 180 billion Iranian rials and were implemented by the Tabriz Water and Wastewater Company. Constraints of government projects require to use various contract methods for delivery. The results showed that the suggested priority included the BOT, BOOT, and DBOT contracts. The type and location of implementation of the project is essential to attract investments, and the city of Tabriz, due to its proximity to the Turkish border and its strong relations with them, is the target of various investments in urban projects.

Rezaei et al. [34] investigated various contracts used by water and wastewater companies and selected the best contract method based on the characteristics of the project. Structured interviews were conducted in the two fields of wastewater network construction and water treatment plant construction to identify the factors that influence the selection of contracts and the ultimate success or failure of these projects. The contract methods for a water and wastewater company were ranked using SAW (simple additive weighting) and TOPSIS techniques. Prioritization results showed that a domestic financial contract is the 
best type of contract for the construction of wastewater networks. For the construction of a water treatment plant, engineering-procurement-construction-finance (EPCF), BOT, and reciprocal contracts have the best and similar scores. Sajedi and Hamze [33] identified and evaluated the risks of trilateral contracts for urban wastewater projects in Ahwaz. They used descriptive field studies and expert opinions to optimize risk for important wastewater projects to identify risks recognized by contract parties (employers and contractors). The resulting matrix can be used as an inseparable part of the trilateral contracts used in Ahwaz urban wastewater projects, to prevent legal claims and conflicts resulting from inaccurate risk allocation.

Amiri and Movaed [38] investigated the advantages of EPC contracts and their role in water and wastewater projects. Their study provides a general description of EPC contracts while investigating the use of this type of contract in WWP. According to the general definition, EPC contracts include three main components: engineering, procurement, and construction. This means that proper management, timely completion, cost prediction, and risk assessment are critical to the success of EPC projects. The main characteristics of EPC contracts are reduced implementation time and increased project gains, which helps them increase their adoption rate. Mahdavi et al. [31] investigated the financing of the design and construction of WWPs. Their study explained the financing and project implementation methods and considered the advantages and disadvantages of each. Then, after considering the economic situation of the country, sanctions, and the emphasis on internal products and investments, they attempted to provide an innovative approach to financing, using investments from the private sector and a combination of various methods. In the proposed approach, the private sector develops water and wastewater networks using private financing and uses the utilities until the investment has been recouped and the necessary gains are achieved. The new financing methods help to increase the speed of WWPs.

Abbaszedeh et al. [39] investigated various challenges of cooperative water and wastewater projects, using criteria evaluation and contract details. They also provided a model for decision-making that results in attracting private sector investors to the projects. The study showed that factors related to employers play the most crucial role in the decisions of large contracts. Therefore, it can be concluded that employer obligations and cooperation with contractors can result in mutual satisfaction and eventual success of these projects.

The criteria for assigning contracts to contractors in projects of water and wastewater companies were investigated by Merati and Nili [32]. They provided a review of the literature on contractor selection for various projects, identified the best contractor selection criteria for water and wastewater companies, and provided a conceptual model. Fakhari [40] proposed a project management system based on the high score of some contracts. As shown in Table 1, based on the review of the existing literature on infrastructure projects in water and wastewater in Iran, it shows that bilateral, trilateral, quadripartite, and cooperative contracts are commonly used in this sector.

Table 1. Contracting methods for water and wastewater projects in Iran.

\begin{tabular}{ccc}
\hline Contract Type & Influencing Factors & Reference \\
\hline DBOT, DB, BOOT, BOT & Financial & {$[30]$} \\
BOT, EPCF & Financial & {$[34]$} \\
Trilateral & Legal and contractual & {$[33]$} \\
EPC & Project goals & {$[38]$} \\
Cooperative & Financial & {$[31]$} \\
Cooperative & Management and organizational & {$[39]$} \\
Cooperative & Technical and technological & {$[32]$} \\
Quadripartite & Management and organizational & {$[40]$} \\
\hline
\end{tabular}




\section{Research Methods}

This section discusses the various research approaches adopted towards prioritizing contract methods for water and wastewater projects. A mixed research design approach was adopted, which involves a review of the literature and the use of the Delphi survey, as well as the FAHP-based expert survey to rank the four types of contracts based on the identified criteria (see Figure 1). The literature review was carried out through content analysis (see [37,41,42]) to deduce the essential criteria that affect the selection of contracting methods. The Delphi survey technique guidelines provided by Hasson et al. [43] and Olawumi and Chan [35] helped design the Delphi survey.

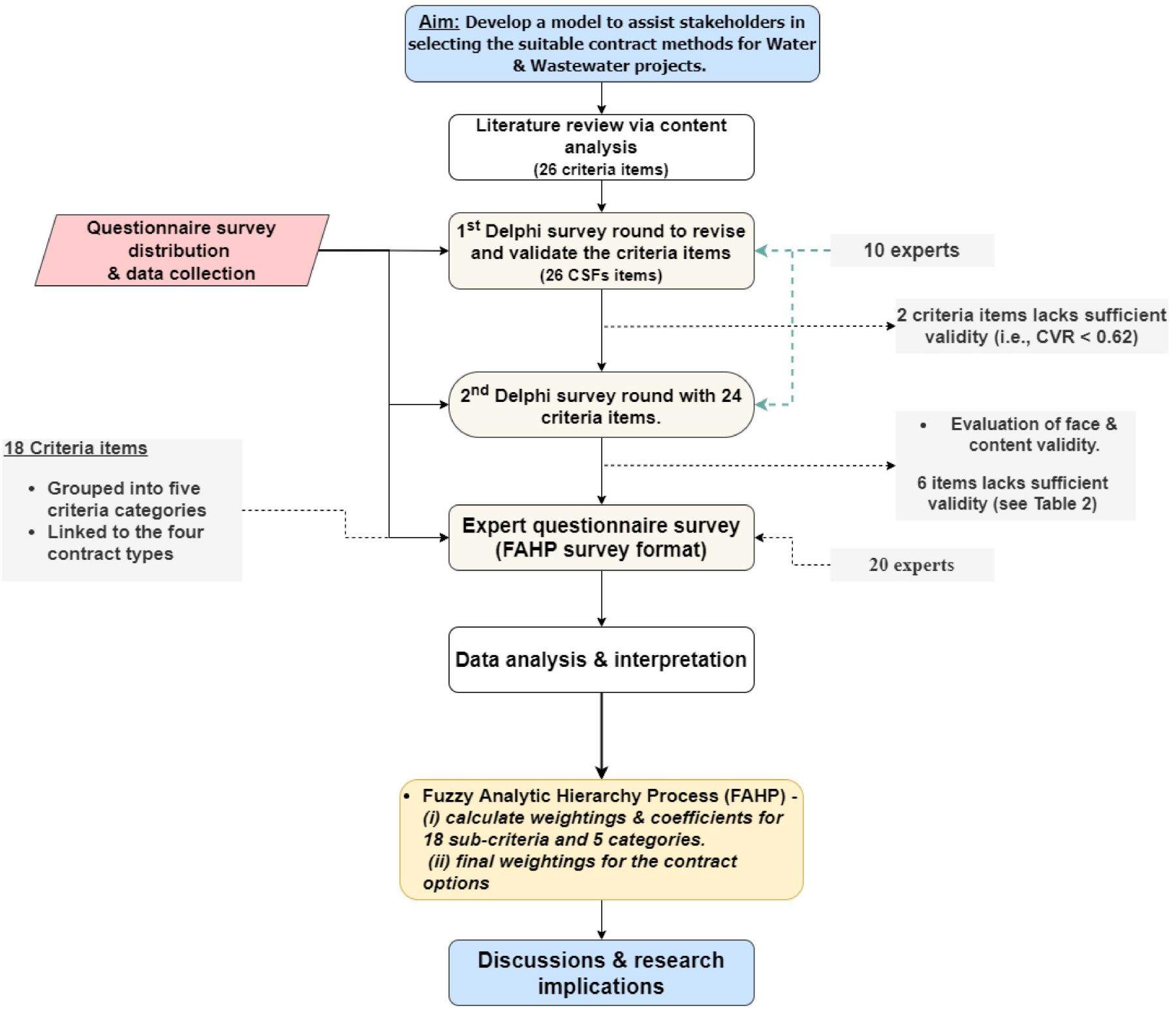

Figure 1. Overall research design of the study.

After identifying the criteria or factors, a Delphi questionnaire with 26 items was developed, which was distributed to 10 experts who were also asked their opinions on contract methods in Iranian water and wastewater projects [44]. After gathering the opinions of the experts, the data was analyzed, reviewed and distributed to the experts for the second round Delphi survey. After the Delphi round, the questionnaire was revised, which gives 24 items. 


\subsection{Evaluation of Content and Face Validity}

Validity is an 'accuracy measure' of the study and shows the degree to which an item correctly measures what it is intended to measure [45]. In the current study, 10 individuals participated in the validity evaluation process. The inclusion criterion was to have at least one hour of free time to complete the questionnaire. The content validity ratio $(C V R)$ and the content validity index $(C V I)$ were used to measure the validity of the questionnaire [46].

\subsubsection{Content Validity Ratio}

Lawshe [47] was the first to introduce the content validity ratio (CVR), which is used to measure the validity of the content, using the opinion of experts in the field being investigated. Consequently, after explaining the purpose of the study and providing them with definitions of the content of the items, experts were asked to score each item using a 3-point Likert scale ( 1 = necessary, 2 = useful, but not necessary, and 3 = unnecessary). The CVR was then calculated as:

$$
C V R=\frac{\left[n-\frac{N}{2}\right]}{\frac{N}{2}},
$$

where $N$ is the total number of experts and $n$ is the number of experts who have selected the 'necessary' score for that item. The number of experts interviewed determines the acceptable cut-off limit for $C V R$, which is equal to 0.62 for ten experts. Items with $C V R$ below the cutoff limit are removed from the questionnaire due to the lack of suitable content validity [48-50].

\subsubsection{Content Validity Index}

The Waltz-Bausell approach [51] was used to evaluate the content validity index (CVI). To this end, experts first score the relevance, clarity, and simplicity of each item on a 4-point Likert scale. For relevance, experts assign scores of $1=$ irrelevant, 2 = somewhat relevant, $3=$ relevant, and $4=$ fully relevant. Regarding simplicity, the scoring options include $1=$ not simple, $2=$ somewhat simple, $3=$ simple, and $4=$ simple and relevant. For clarity, the scoring options include $1=$ unclear, $2=$ somewhat clear, $3=$ clear, and $4=$ clear and relevant. The CVI is calculated as follows:

$$
\text { Content Validity Index }(C V I)=\frac{\text { Number of raters giving of } 3 \text { and } 4}{\text { Total number of raters }} \text {, }
$$

The minimum cut-off value for the $C V I$ is 0.79 , and items with a CVI below 0.79 are eliminated from the questionnaire [52].

\subsubsection{Evaluation of Face Validity}

Face validity is one of the basic requirements for each item. This type of validity shows whether the items can measure the intended study variables at face value. An item impact score is used to measure the face validity of the items. Participants are first asked to score the importance of each item on a 5-point Likert scale, from 1 (unimportant) to 5 (very important) to determine the impact scores of the item. The scores include $5=$ very important, $4=$ important, $3=$ somewhat important, $2=$ of little importance, and $1=$ unimportant. Then, the impact scores of the items are calculated as follows:

$$
\text { Impact score }=\text { Frequency }(\%) \times \text { Importance, }
$$

For acceptance of the face validity of an item, its score must not be below 1.5. Consequently, items with impact scores of 1.5 or higher are retained [52,53].

\subsubsection{Evaluation Results of Face and Content Validity}

The evaluation results for the content and face validity showed that only 18 items (of the 24 items) had suitable content and face validity (see Table 2). In fact, based on the 
face validity results, the criteria of 'minimize contracting party factors' and 'need to do basic studies' with scores below 1.5 were eliminated from the survey. Furthermore, by calculating CVI in the four rounds of the Delphi survey, six of the criteria were eliminated from the survey, including 'reduce or transfer risk to contractor', 'minimize contracting party factors, 'employer's characteristics and experience in performing similar projects', 'need to do basic studies', 'compliance of contract coefficients with project status', and 'legal restrictions'. The calculated CVI for these criteria was below 0.79. Additionally, the calculated $C V R$ for five criteria was below 0.62 , so these criteria were removed. These criteria include 'reduce or transfer risk to contractor', 'minimize contracting party factors', 'employer's characteristics and experience in performing similar projects', 'need to do basic studies', 'compliance of contract coefficients with project status'.

Table 2. Results of the face and content validity.

\begin{tabular}{|c|c|c|c|c|c|c|c|}
\hline \multirow{2}{*}{ No } & \multirow{2}{*}{ Criteria } & \multirow{2}{*}{$\begin{array}{l}\text { Face Validity } \\
\text { Results }\end{array}$} & \multicolumn{5}{|c|}{ Content Validity Results } \\
\hline & & & CVI-1 & CVI-2 & CVI-3 & CVI-4 & $C V R$ \\
\hline 1 & Reduce or transfer risk to contractor & $\sqrt{ }$ & $\sqrt{ }$ & $x$ & $\sqrt{ }$ & $x$ & $x$ \\
\hline 2 & Minimize contracting party factors & $x$ & $x$ & $\sqrt{ }$ & $\sqrt{ }$ & $x$ & $x$ \\
\hline 3 & Maximize the controlling role of employer & $\sqrt{ }$ & $\sqrt{ }$ & $\sqrt{ }$ & $\sqrt{ }$ & $\sqrt{ }$ & $\sqrt{ }$ \\
\hline 4 & Effect of supervision system & $\sqrt{ }$ & $\sqrt{ }$ & $\sqrt{ }$ & $\sqrt{ }$ & $\sqrt{ }$ & $\sqrt{ }$ \\
\hline 5 & Employer's ability to manage and control projects & $\sqrt{ }$ & $\sqrt{ }$ & $\sqrt{ }$ & $\sqrt{ }$ & $\sqrt{ }$ & $\sqrt{ }$ \\
\hline 6 & $\begin{array}{c}\text { Employer's characteristics and experience in performing } \\
\text { similar projects }\end{array}$ & $\sqrt{ }$ & $\times$ & $\sqrt{ }$ & $\sqrt{ }$ & $\times$ & $\times$ \\
\hline 7 & Stakeholder satisfaction & $\sqrt{ }$ & $\sqrt{ }$ & $\sqrt{ }$ & $\sqrt{ }$ & $\sqrt{ }$ & $\sqrt{ }$ \\
\hline 8 & Inflation (national economic situation) & $\sqrt{ }$ & $\sqrt{ }$ & $\sqrt{ }$ & $\sqrt{ }$ & $\sqrt{ }$ & $\sqrt{ }$ \\
\hline 9 & Certainty of project financing & $\sqrt{ }$ & $\sqrt{ }$ & $\sqrt{ }$ & $\sqrt{ }$ & $\sqrt{ }$ & $\sqrt{ }$ \\
\hline 10 & Project's total value & $\sqrt{ }$ & $\sqrt{ }$ & $\sqrt{ }$ & $\sqrt{ }$ & $\sqrt{ }$ & $\sqrt{ }$ \\
\hline 11 & Possibility of financing increase by the contractor & $\sqrt{ }$ & $\sqrt{ }$ & $\sqrt{ }$ & $\sqrt{ }$ & $\sqrt{ }$ & $\sqrt{ }$ \\
\hline 12 & Design specifications (design complexity) & $\sqrt{ }$ & $\sqrt{ }$ & $\sqrt{ }$ & $\sqrt{ }$ & $\sqrt{ }$ & $\sqrt{ }$ \\
\hline 13 & $\begin{array}{l}\text { Technical and implementation details (specific technological } \\
\text { requirements for implementation) }\end{array}$ & $\sqrt{ }$ & $\sqrt{ }$ & $\sqrt{ }$ & $\sqrt{ }$ & $\sqrt{ }$ & $\sqrt{ }$ \\
\hline 14 & Safety, health, and environmental concerns & $\sqrt{ }$ & $\sqrt{ }$ & $\sqrt{ }$ & $\sqrt{ }$ & $\sqrt{ }$ & $\sqrt{ }$ \\
\hline 15 & Ease of change & $\sqrt{ }$ & $\sqrt{ }$ & $\sqrt{ }$ & $\sqrt{ }$ & $\sqrt{ }$ & $\sqrt{ }$ \\
\hline 16 & Need to do basic studies & $\times$ & $\times$ & $\sqrt{ }$ & $x$ & $\sqrt{ }$ & $x$ \\
\hline 17 & Compliance of contract coefficients with project status & $\sqrt{ }$ & $x$ & $x$ & $x$ & $\times$ & $x$ \\
\hline 18 & Ease of conflict resolution & $\sqrt{ }$ & $\sqrt{ }$ & $\sqrt{ }$ & $\sqrt{ }$ & $\sqrt{ }$ & $\sqrt{ }$ \\
\hline 19 & Payment method for contractors & $\sqrt{ }$ & $\sqrt{ }$ & $\sqrt{ }$ & $\sqrt{ }$ & $\sqrt{ }$ & $\sqrt{ }$ \\
\hline 20 & Observing requirements for selection of qualified contractors & $\sqrt{ }$ & $\sqrt{ }$ & $\sqrt{ }$ & $\sqrt{ }$ & $\sqrt{ }$ & $\sqrt{ }$ \\
\hline 21 & Legal restrictions & $\sqrt{ }$ & $\sqrt{ }$ & $x$ & $x$ & $\sqrt{ }$ & $\sqrt{ }$ \\
\hline 22 & $\begin{array}{l}\text { Importance of timely completion of the project (time } \\
\text { as priority) }\end{array}$ & $\sqrt{ }$ & $\sqrt{ }$ & $\sqrt{ }$ & $\sqrt{ }$ & $\sqrt{ }$ & $\sqrt{ }$ \\
\hline 23 & Importance of cost of the project (cost as priority) & $\sqrt{ }$ & $\sqrt{ }$ & $\sqrt{ }$ & $\sqrt{ }$ & $\sqrt{ }$ & $\sqrt{ }$ \\
\hline 24 & Importance of performance of the project (quality as priority) & $\sqrt{ }$ & $\sqrt{ }$ & $\sqrt{ }$ & $\sqrt{ }$ & $\sqrt{ }$ & $\sqrt{ }$ \\
\hline
\end{tabular}

\subsection{Reliability of the Questionnaire}

After evaluating the reliability of the questionnaire, items with low reliability were eliminated to increase the overall reliability of the questionnaire. Various methods can be used to determine reliability. In the current study, SPSS software was used to calculate the Cronbach alpha coefficient to determine the reliability of the questionnaire. The cut-off value for Cronbach's alpha is 0.70 [54-57], and Cronbach's alpha in the current study was 0.958 , indicating that the 18 remaining elements of contract selection achieved satisfactory reliability.

\section{The Fuzzy Analytic Hierarchy Process}

\subsection{Decision Tree}

In the current study, a decision tree was used to prioritize the contracting methods used in Iranian water and wastewater projects. Figure 2 presents the framework for the 
fuzzy analytic hierarchy process (FAHP) method. This decision tree included five key selection criteria, 18 sub-criteria, and four options. The codes used for the options, key criteria, and sub-criteria are presented in Tables 3 and 4.

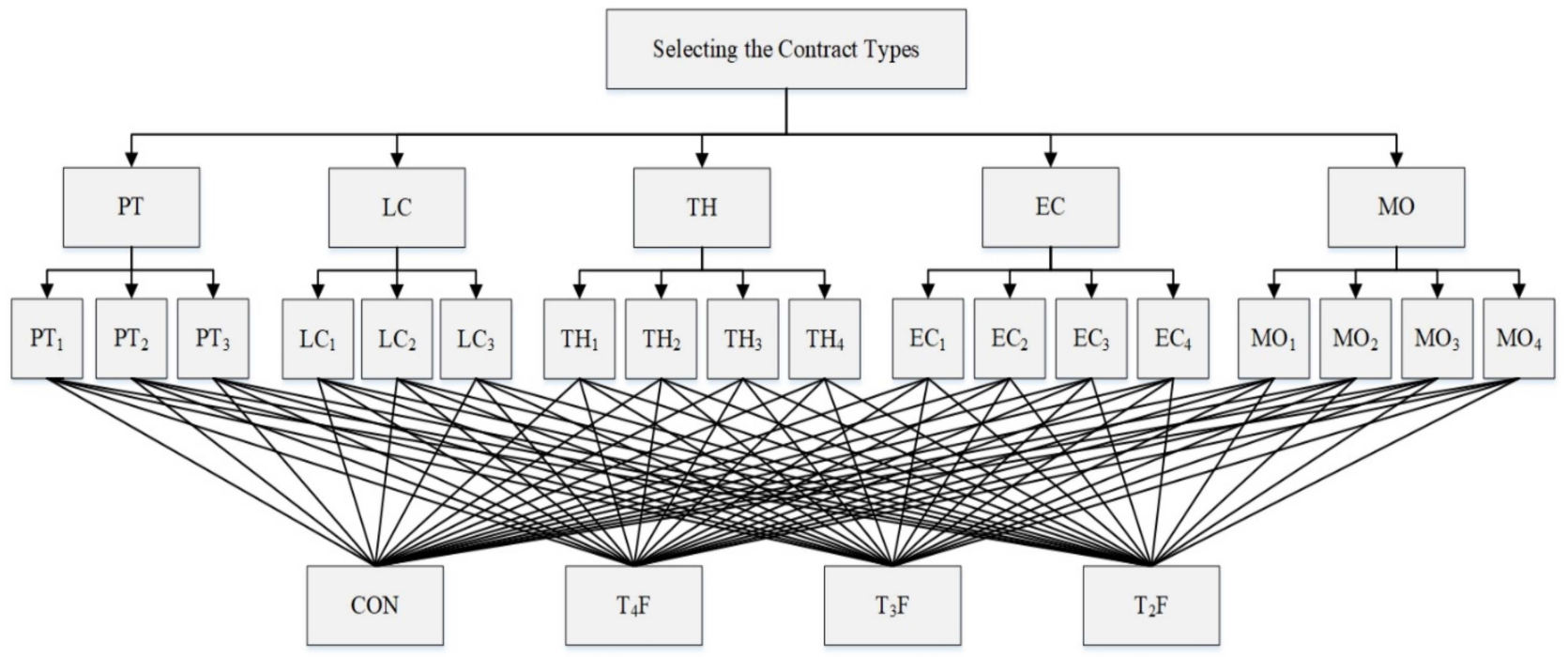

Figure 2. Decision tree used in the current study.

Table 3. The coding of options.

\begin{tabular}{ccc}
\hline Code & Option & Methods \\
\hline $\mathrm{T}_{2} \mathrm{~F}$ & Bilateral & DB/EPC/EPCF \\
$\mathrm{T}_{3} \mathrm{~F}$ & Trilateral & Trilateral \\
$\mathrm{T}_{4} \mathrm{~F}$ & Quadripartite & Construction Management (CM) \\
$\mathrm{CON}$ & Cooperative & Public Private Partnership (PPP) \\
\hline
\end{tabular}

Table 4. The coding of selection key criteria and sub-criteria.

\begin{tabular}{|c|c|c|c|}
\hline No & Key Criteria & Sub-Criteria & Code \\
\hline $\begin{array}{l}1 \\
2 \\
3 \\
4\end{array}$ & Management and organizational & $\begin{array}{c}\text { Maximize the controlling role of employer } \\
\text { Effect of supervision system } \\
\text { Employer's ability to manage and control projects } \\
\text { Stakeholder satisfaction }\end{array}$ & $\begin{array}{l}\mathrm{MO} \\
\mathrm{MO}_{1} \\
\mathrm{MO}_{2} \\
\mathrm{MO}_{3} \\
\mathrm{MO}_{4}\end{array}$ \\
\hline $\begin{array}{l}5 \\
6 \\
7 \\
8\end{array}$ & Economic & $\begin{array}{c}\text { Inflation (national economic situation) } \\
\text { Certainty of project financing } \\
\text { Project's total value } \\
\text { Possibility of financing increase by the contractor }\end{array}$ & $\begin{array}{l}\mathrm{EC} \\
\mathrm{EC}_{1} \\
\mathrm{EC}_{2} \\
\mathrm{EC}_{3} \\
\mathrm{EC}_{4}\end{array}$ \\
\hline $\begin{array}{l}9 \\
10 \\
11 \\
12\end{array}$ & Technological and technical & $\begin{array}{c}\text { Design specifications (design complexity) } \\
\text { Technical and implementation details (specific technological } \\
\text { requirements for implementation) } \\
\text { Safety, health, and environmental concerns } \\
\text { Ease of change }\end{array}$ & $\begin{array}{l}\mathrm{TH} \\
\mathrm{TH}_{1} \\
\mathrm{TH}_{2} \\
\mathrm{TH}_{3} \\
\mathrm{TH}_{4}\end{array}$ \\
\hline $\begin{array}{l}13 \\
14 \\
15\end{array}$ & Legal and contractual & $\begin{array}{c}\text { Ease of conflict resolution } \\
\text { Payment method for contractors } \\
\text { Observing requirements for selection of qualified contractors }\end{array}$ & $\begin{array}{l}\mathrm{LC} \\
\mathrm{LC}_{1} \\
\mathrm{LC}_{2} \\
\mathrm{LC}_{3}\end{array}$ \\
\hline $\begin{array}{l}16 \\
17 \\
18\end{array}$ & Project goals & $\begin{array}{l}\text { Importance of timely completion of the project } \\
\text { Importance of cost of the project } \\
\text { Importance of performance of the project }\end{array}$ & $\begin{array}{l}\mathrm{PT} \\
\mathrm{PT}_{1} \\
\mathrm{PT}_{2} \\
\mathrm{PT}_{3}\end{array}$ \\
\hline
\end{tabular}


After the contracting methods were prioritized, the target audience of the current study, which included 20 experts involved in water and wastewater projects in Isfahan province, was asked to complete the pairwise comparison questionnaire used for the FAHP method. This study used verbal statements instead of definitive numerical values to weigh and rank options. Table 5 shows a comparison of the verbal statements that were used to describe the importance of the selection criteria.

Table 5. Verbal statements for pairwise comparisons and degree of importance [58].

\begin{tabular}{ccc}
\hline Fuzzy Number & Verbal Statement & Fuzzy Number Scale \\
\hline 1 & Equal & $(1,1,1)$ \\
2 & Very small superiority & $(1,2,3)$ \\
3 & Small superiority & $(2,3,4)$ \\
4 & Superiority & $(3,4,5)$ \\
5 & Good & $(4,5,6)$ \\
6 & Relatively good & $(5,6,7)$ \\
7 & Very good & $(6,7,8)$ \\
8 & Great & $(7,8,9)$ \\
9 & Absolute superiority & $(8,9,10)$ \\
\hline
\end{tabular}

\subsection{The Process of FAHP Method}

The extent analysis method (EA) was first introduced in 1996 by Young Cheng. The numbers used in this approach are a fuzzy triangle [59]. Taking into account the two triangle fuzzy numbers of $M_{1}=\left(l_{1}, m_{1}, u_{1}\right)$ and $M_{2}=\left(l_{2}, m_{2}, u_{2}\right)$, Equation (4) can be written as follows:

$$
\begin{gathered}
M_{1}+M_{2}=\left(l_{1}+l_{2}, m_{1}+m_{2}, u_{1}+u_{2}\right) \\
M_{1} \cdot M_{2}=\left(l_{1} l_{2}, m_{1} m_{2}, u_{1} u_{2}\right) \\
M_{1}^{-1}=\left(\frac{1}{u_{1}}, \frac{1}{m_{1}}, \frac{1}{l_{1}}\right) \\
M_{2}^{-1}=\left(\frac{1}{u_{2}}, \frac{1}{m_{2}}, \frac{1}{l_{2}}\right) .
\end{gathered}
$$

It should be noted that the product of the two triangular fuzzy numbers (TFN) of the inverse of a fuzzy triangle number is not a fuzzy triangle number. Furthermore, these equations show only an estimation of the real product of two fuzzy triangle numbers and the inverse of a fuzzy triangle number. In the extended analysis method (EA), the value of $S_{k}$, which is a fuzzy triangle number, is calculated for each row of the pairwise comparison matrix as:

$$
S_{k}=\sum_{j=1}^{n} M_{k j} \times\left[\sum_{i=1}^{m} \sum_{j=1}^{n} M_{i j}\right]^{-1}
$$

$k$ is the number of rows, and $i$ and $j$ are the options and indices.

In this method, after calculating $S_{k}$, a comparison of their degrees of magnitude should be made. In general, if $M_{1}$ and $M_{2}$ are two triangle fuzzy numbers, the degree of magnitude of $M_{1}$ compared to $M_{2}$ is defined using the following:

$$
\begin{cases}V\left(M_{2} \leq M_{1}\right)=1 & \text { if } m_{2} \geq m_{1} \\ 0 & \text { if } u_{2} \geq l_{1} \\ V\left(M_{2} \geq M_{1}\right)=\operatorname{hgt}\left(M_{1} \cap M_{2}\right) & \text { otherwise }\end{cases}
$$

Furthermore, based on the similarity properties of triangles, we can say:

$$
\operatorname{hgt}\left(M_{1} \cap M_{2}\right)=\frac{u_{1}-L_{2}}{\left(u_{1}-L_{2}\right)+\left(m_{2}-m_{1}\right)}
$$


The degree of magnitude of a fuzzy triangle number from $\mathrm{k}$ and other fuzzy triangle numbers is calculated:

$$
V\left(M_{1} \geq M_{2}, \ldots, M_{k}\right)=V\left(M_{1} \geq M_{2}\right) \text { and } \ldots \text { and } V\left(M_{1} \geq M_{k}\right)
$$

The weights of the indices in a pairwise comparison matrix are defined as follows.

$$
W^{\prime}\left(x_{i}\right)=\min \left\{V\left(S_{i} \geq S_{k}\right)\right\} \quad k=1,2, \ldots, n \quad, k \neq i
$$

$k$ is the number of rows, and $i$ and $j$ are the options and indices.

Therefore, the weight vector for the indices is calculated:

$$
W^{\prime}=\left[W^{\prime}\left(x_{1}\right), W^{\prime}\left(x_{2}\right), \ldots, W^{\prime}\left(x_{n}\right)\right]^{t}
$$

which is the same as the non-normal fuzzy vector [59-61].

\subsection{Calculation of Compatibility Rate}

The Gogus and Boucher approach [62] was used to calculate the compatibility rate in the current study. They suggested using the clock method to evaluate the compatibility of two matrices (the middle number and fuzzy number limits); this makes it possible to derive each fuzzy matrix before calculating its compatibility. The steps to calculate the compatibility rate in fuzzy pairwise comparison matrices are as follows.

Step 1. The fuzzy triangle matrix is divided into two matrices. The first matrix is made from the middle numbers of the verdicts of the initial matrix $\left(A_{m}=\left[a_{i j m}\right]\right)$, while the second matrix is the geometric mean of the upper and lower limits of triangle numbers $\left(A^{g}=\sqrt{a_{i j u} a_{i j l}}\right)$.

Step 2. The weight of each matrix is calculated using the clock approach.

Step 3. The largest eigenvalue for each matrix is calculated.

Step 4. The compatibility index is calculated as:

$$
\begin{gathered}
C I^{m}=\frac{\left(\lambda_{\text {max }}^{m}-n\right)}{(n-1)} \\
C I^{g}=\frac{\left(\lambda_{\text {max }}^{g}-n\right)}{(n-1)}
\end{gathered}
$$

Step 5. To calculate the compatibility rate $(C R)$, the compatibility index $(C I)$ is divided by the random index $(R I)$. If the result is less than 0.1 , the matrix is compatible and usable for data evaluation. Following Saaty's procedure, 100 matrices are created with random numbers and the condition of being crosswise, and their CI and mean CI are calculated. Since the numerical numbers for fuzzy comparisons are not always integers and can be non-integer numbers due to the geometrical mean, yet the Saaty 1-9 scale cannot be used to create the table of random indices (RI). Therefore, Gogus and Boucher [54] used 400 random matrices to generate a table of $R I$ values to compare fuzzy pairwise comparison matrices, that is:

$$
\begin{aligned}
C R^{m} & =\frac{C I^{m}}{R I^{m}} \\
C R^{g} & =\frac{C I^{g}}{R I^{g}}
\end{aligned}
$$

If both of these indices are less than 0.1 , then the fuzzy matrix is compatible; however, if both indices are higher than 0.1 , the decision-maker is asked to revise the prioritization. Suppose that only the $C R^{m}\left(C R^{g}\right)$ is greater than 0.1 . In that case, the decision maker must adjust the median value of the fuzzy verdict [63-67]. 


\section{Analytical Results and Discussion of Findings}

Data analysis of the FAHP method was performed in Excel. The final weight of options, the weight coefficients, compatibility rates, and the options ranked by the weight for each sub-criterion are given in Tables 6-9. Figure 3 shows the final weight of the options based on eight criteria and 18 sub-criteria. As shown in Table 6, management and organizational criteria $(\mathrm{MO})$ have the highest weight (0.383), followed by economic criteria (EC) (0.212), indicating that these two criteria groups greatly influence the selection for contract types of water and wastewater projects in Iran. The project goals (PT) and the legal and contractual criteria (LC) were scored 0.044 and 0.033 , respectively, while the technological and technical criteria (TH) had the lowest weight $(0.007)$, indicating their negligible influence in the selection of the contracting method.

Among the sub-criteria of management and organizational group, the effectiveness of supervision systems $\left(\mathrm{MO}_{2}\right)$, the employer's ability to manage and control projects $\left(\mathrm{MO}_{3}\right)$ had a higher score compared to stakeholder satisfaction $\left(\mathrm{MO}_{4}\right)$ and maximization of the control role of the employer $\left(\mathrm{MO}_{1}\right)$. The prioritization of management and organizational sub-criteria is similar to the results of the study by Abbaszedeh et al. [39] that showed that factors related to employers play a crucial role in the selection of the contract for WWP. Meanwhile, the economic sub-criteria rank according to the importance are as follows: inflation (national economic situation) $\left(\mathrm{EC}_{1}\right)$ (the most important), the certainty of project financing $\left(\mathrm{EC}_{2}\right)$, the possibility of financing increase by the contractor $\left(\mathrm{EC}_{4}\right)$, and the project's total value $\left(\mathrm{EC}_{3}\right)$ (the least important). Furthermore, the findings of this study are consistent with previous studies such as Mahdavi et al. [31], which identified innovative financing approaches by the private sector as a key factor that accelerates the completion of a project. Safety, health and environmental concerns $\left(\mathrm{TH}_{3}\right)$, ease of change $\left(\mathrm{TH}_{4}\right)$, design specifications $\left(\mathrm{TH}_{1}\right)$, and technical and implementation details $\left(\mathrm{TH}_{2}\right)$ were ranked from the highest to lowest weight, respectively, in the technical and technological criteria group. According to Shirali et al. [50], a good safety culture is often viewed as a capability or as an absence of injuries and accidents, which also confirms the results obtained in this study.

Furthermore, observing the requirements for the selection of qualified contractors $\left(\mathrm{LC}_{3}\right)$ was the most important, followed by the ease of conflict resolution $\left(\mathrm{LC}_{1}\right)$, and the payment method for contractors $\left(\mathrm{LC}_{2}\right)$ was the least important among the legal and contractual criteria. Finally, the project goals according to importance are ranked as follows: the cost of the project $\left(\mathrm{PT}_{2}\right)$ (the most important), the performance of the project $\left(\mathrm{PT}_{3}\right)$, and the timely completion of the project $\left(\mathrm{PT}_{1}\right)$ (the least important). Previous studies by Roustaei [30] and Sajedi and Hamze [33] identified cost, time, conflict resolution, and risk due to inflation as key factors that affect the selection of contract methods, which aligns with the findings of this study.

Table 6 tabulates the ranking of contracting options according to each sub-criterion. The analysis of the results revealed that the 'bilateral' option is the preferred option, which has the highest weight for more than $70 \%$ of sub-criteria (13 out of 18 ), followed by the cooperative, trilateral, and quadripartite options. In addition, the bilateral option shows its precedence for the two most influential criteria: this contract method was ranked as the first for all sub-criteria in the management and organizational criteria (MO) group and in the economic criteria (EC) group except for sub-criterion $\mathrm{EC}_{4}$ (i.e., possibility of financing increase by the contractor).

The results revealed that the bilateral option might be the preferred option for selecting the type of contract for WWP in Iran. As expected, the bilateral option with a score of 0.326 recorded the highest weight among all options, as can be seen in Figure 3, followed by the cooperative option (0.287). On the contrary, the quadripartite option has the least weight. The compatibility rate of all comparisons was below 0.1 , indicating that all comparison pairs are acceptable. The study findings are consistent with the prioritization results reported by Rezaei et al. [34] that show that bilateral agreement is the best type of contract in water and wastewater projects. 
Table 6. Summary of final weights.

\begin{tabular}{|c|c|c|c|c|c|c|c|c|c|c|c|c|c|c|c|c|c|c|}
\hline & \multicolumn{4}{|c|}{ MO } & \multicolumn{4}{|c|}{ EC } & \multicolumn{4}{|c|}{ TH } & \multicolumn{3}{|c|}{ LC } & \multicolumn{3}{|c|}{ PT } \\
\hline & \multicolumn{4}{|c|}{0.383} & \multicolumn{4}{|c|}{0.212} & \multicolumn{4}{|c|}{0.007} & \multicolumn{3}{|c|}{0.033} & \multicolumn{3}{|c|}{0.044} \\
\hline & $\mathbf{M O}_{1}$ & $\mathrm{MO}_{2}$ & $\mathrm{MO}_{3}$ & $\mathrm{MO}_{4}$ & $\mathrm{EC}_{1}$ & $\mathrm{EC}_{2}$ & $\mathrm{EC}_{3}$ & $\mathrm{EC}_{4}$ & $\mathrm{TH}_{1}$ & $\mathrm{TH}_{2}$ & $\mathrm{TH}_{3}$ & $\mathrm{TH}_{4}$ & $\mathrm{LC}_{1}$ & $\mathrm{LC}_{2}$ & $\mathrm{LC}_{3}$ & $\mathrm{PT}_{1}$ & $\mathrm{PT}_{2}$ & $\mathrm{PT}_{3}$ \\
\hline & 0.216 & 0.327 & 0.231 & 0.226 & 0.284 & 0.251 & 0.222 & 0.244 & 0.219 & 0.212 & 0.297 & 0.272 & 0.309 & 0.229 & 0.462 & 0.316 & 0.345 & 0.339 \\
\hline $\mathrm{T}_{2} \mathrm{~F}$ & 0.302 & 0.276 & 0.304 & 0.289 & 0.364 & 0.290 & 0.318 & 0.365 & 0.314 & 0.430 & 0.337 & 0.373 & 0.341 & 0.361 & 0.417 & 0.366 & 0.314 & 0.368 \\
\hline $\mathrm{T}_{3} \mathrm{~F}$ & 0.265 & 0.236 & 0.249 & 0.229 & 0.226 & 0.256 & 0.231 & 0.205 & 0.242 & 0.132 & 0.293 & 0.174 & 0.238 & 0.272 & 0.224 & 0.311 & 0.162 & 0.256 \\
\hline $\mathrm{T}_{4} \mathrm{~F}$ & 0.209 & 0.219 & 0.178 & 0.218 & 0.100 & 0.190 & 0.150 & 0.077 & 0.182 & 0.080 & 0.081 & 0.148 & 0.095 & 0.037 & 0.100 & 0.062 & 0.211 & 0.121 \\
\hline $\mathrm{CON}$ & 0.223 & 0.269 & 0.269 & 0.265 & 0.311 & 0.265 & 0.300 & 0.352 & 0.261 & 0.358 & 0.289 & 0.305 & 0.327 & 0.330 & 0.259 & 0.261 & 0.312 & 0.255 \\
\hline
\end{tabular}

Table 7. Weight coefficients.

\begin{tabular}{|c|c|c|c|c|c|c|c|c|c|c|c|c|c|c|c|c|c|c|}
\hline & $\mathbf{M O}_{1}$ & $\mathrm{MO}_{2}$ & $\mathrm{MO}_{3}$ & $\mathrm{MO}_{4}$ & $\mathrm{EC}_{1}$ & $\mathrm{EC}_{2}$ & $\mathrm{EC}_{3}$ & $\mathrm{EC}_{4}$ & $\mathrm{TH}_{1}$ & $\mathrm{TH}_{2}$ & $\mathrm{TH}_{3}$ & $\mathrm{TH}_{4}$ & $\mathrm{LC}_{1}$ & $\mathrm{LC}_{2}$ & $\mathrm{LC}_{3}$ & $\mathrm{PT}_{1}$ & $\mathrm{PT}_{2}$ & $\mathrm{PT}_{3}$ \\
\hline $\mathrm{T}_{2} \mathrm{~F}$ & 0.023 & 0.032 & 0.025 & 0.023 & 0.039 & 0.028 & 0.027 & 0.034 & 0.015 & 0.019 & 0.021 & 0.021 & 0.001 & 0.001 & 0.001 & 0.005 & 0.005 & 0.005 \\
\hline $\mathrm{T}_{3} \mathrm{~F}$ & 0.020 & 0.027 & 0.000 & 0.018 & 0.024 & 0.000 & 0.000 & 0.019 & 0.011 & 0.006 & 0.000 & 0.010 & 0.001 & 0.000 & 0.000 & 0.004 & 0.000 & 0.000 \\
\hline $\mathrm{T}_{4} \mathrm{~F}$ & 0.016 & 0.025 & 0.015 & 0.017 & 0.011 & 0.000 & 0.013 & 0.007 & 0.008 & 0.004 & 0.005 & 0.009 & 0.000 & 0.000 & 0.000 & 0.001 & 0.000 & 0.002 \\
\hline $\mathrm{CON}$ & 0.017 & 0.031 & 0.022 & 0.021 & 0.034 & 0.025 & 0.026 & 0.033 & 0.012 & 0.016 & 0.018 & 0.018 & 0.001 & 0.001 & 0.001 & 0.004 & 0.005 & 0.004 \\
\hline
\end{tabular}


Table 9 shows the priority of the options based on any of the criteria. Additionally, Figure 3 shows the ranking of the four options taking into account all the criteria of the research study. It is clear that consideration of the criteria for selecting the contracting methods depends on different parameters, including organization goals, economic situation, technical knowledge, legal factors, and project goals. Therefore, the criteria are different for any project; and the weight of each criterion may be larger or lower than others. In this study, the weight of all types of criteria is assumed equal.

Table 8. Compatibility rate for each item.

\begin{tabular}{ccc}
\hline Item & $C^{g}$ & $C^{g}$ \\
Key Criteria & 0.0855 & 0.0287 \\
Management and organizational criteria & 0.0021 & 0.0006 \\
Economic criteria & 0.0610 & 0.0858 \\
Technological and technical criteria & 0.0604 & 0.0299 \\
Legal and contractual criteria & 0.0260 & 0.0241 \\
Project goals criteria & 0.0953 & 0.0087 \\
Options regarding maximization of the controlling role of employer & 0.0752 & 0.0829 \\
Options regarding effect of supervision system & 0.0827 & 0.0658 \\
Options regarding employer's ability to manage and control projects & 0.0950 & 0.0646 \\
Options regarding stakeholder satisfaction & 0.0672 & 0.0746 \\
Options regarding inflation (national economic situation) & 0.0974 & 0.0597 \\
Options regarding certainty of project financing & 0.0941 & 0.0863 \\
Options regarding project's total value & 0.0872 & 0.0739 \\
Options regarding the possibility of financing increase by the contractor & 0.0738 & 0.0743 \\
Options regarding design specifications (design complexity) & 0.0752 & 0.0932 \\
Options regarding technical and implementation details & 0.0583 & 0.0871 \\
Options regarding safety, health, and environmental concerns & 0.0872 & 0.0435 \\
Options regarding ease of change & 0.0941 & 0.0743 \\
Options regarding ease of conflict resolution & 0.0941 & 0.0839 \\
Options regarding payment method for contractors & 0.0593 & 0.0821 \\
Options regarding the importance of performance of the project & 0.0915 & 0.0762 \\
Options & & 0.0421 \\
Options regarding the importance of cost of the project & 0.0703 \\
\hline
\end{tabular}

Table 9. The options priority order by weight for each sub-criterion.

\begin{tabular}{|c|c|c|c|}
\hline No & Key Criteria & Sub-Criteria & $\begin{array}{c}\text { Options Order by Weight (from Highest } \\
\text { to Lowest) }\end{array}$ \\
\hline $\begin{array}{l}1 \\
2 \\
3 \\
4\end{array}$ & $\begin{array}{l}\text { Management } \\
\text { and } \\
\text { organizational }\end{array}$ & $\begin{array}{l}\text { Maximization of the controlling role of employer } \\
\text { Effect of supervision system } \\
\text { Employer's ability to manage and control projects } \\
\text { Stakeholder satisfaction }\end{array}$ & $\begin{array}{l}\text { Bilateral, trilateral, cooperative, quadripartite } \\
\text { Bilateral, cooperative, trilateral, quadripartite } \\
\text { Bilateral, cooperative, trilateral, quadripartite } \\
\text { Bilateral, trilateral, cooperative, quadripartite }\end{array}$ \\
\hline $\begin{array}{l}5 \\
6 \\
7 \\
8\end{array}$ & Economic & $\begin{array}{c}\text { Inflation (national economic situation) } \\
\text { Certainty of project financing } \\
\text { Project's total value } \\
\text { Possibility of financing increase by the contractor }\end{array}$ & $\begin{array}{l}\text { Bilateral, cooperative, trilateral, quadripartite } \\
\text { Bilateral, trilateral, cooperative, quadripartite } \\
\text { Bilateral, trilateral, cooperative, quadripartite } \\
\text { Trilateral, bilateral, cooperative, quadripartite }\end{array}$ \\
\hline $\begin{array}{c}9 \\
10 \\
11 \\
12\end{array}$ & $\begin{array}{l}\text { Technological } \\
\text { and technical }\end{array}$ & $\begin{array}{c}\text { Design specifications (design complexity) } \\
\text { Technical and implementation details (specific } \\
\text { technological requirements for implementation) } \\
\text { Safety, health, and environmental concerns } \\
\text { Ease of change }\end{array}$ & $\begin{array}{l}\text { Trilateral, bilateral, quadripartite, cooperative } \\
\text { Bilateral, trilateral, cooperative, quadripartite } \\
\text { Bilateral, cooperative, trilateral, quadripartite } \\
\text { Cooperative, bilateral, trilateral, quadripartite }\end{array}$ \\
\hline $\begin{array}{l}13 \\
14 \\
15\end{array}$ & $\begin{array}{l}\text { Legal and } \\
\text { contractual }\end{array}$ & $\begin{array}{c}\text { Ease of conflict resolution } \\
\text { Payment method for contractors } \\
\text { Observing requirements for selection of } \\
\text { qualified contractors }\end{array}$ & $\begin{array}{l}\text { Bilateral, trilateral, cooperative, quadripartite } \\
\text { Cooperative, bilateral, trilateral, quadripartite } \\
\text { Cooperative, bilateral, trilateral, quadripartite }\end{array}$ \\
\hline $\begin{array}{l}16 \\
17 \\
18\end{array}$ & Project goals & $\begin{array}{l}\text { Importance of timely completion of the project } \\
\text { Importance of cost of the project } \\
\text { Importance of performance of the project }\end{array}$ & $\begin{array}{l}\text { Bilateral, cooperative, trilateral, quadripartite } \\
\text { Bilateral, cooperative, trilateral, quadripartite } \\
\text { Bilateral, cooperative, trilateral, quadripartite }\end{array}$ \\
\hline
\end{tabular}




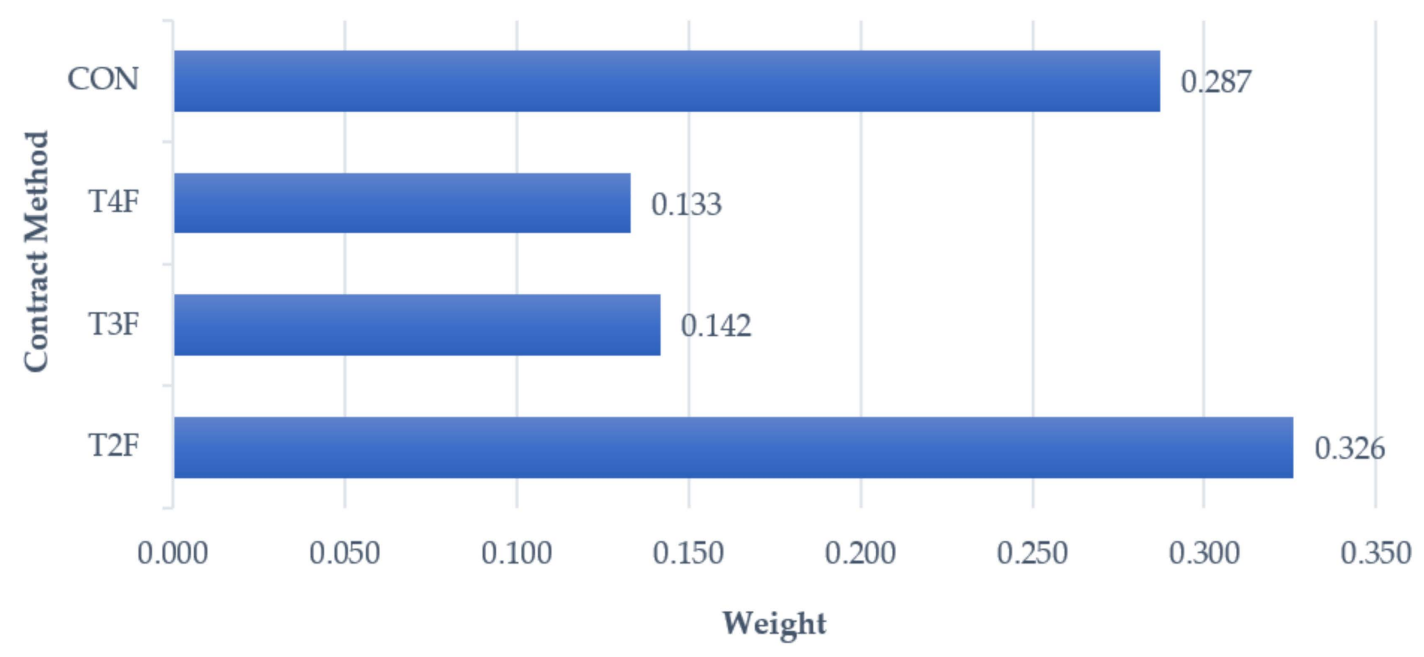

Figure 3. The final weighting of contracting options.

\section{Research Implications}

The selection of the appropriate contracting method is critical to the success of any project.

Practical implications. The study provided practitioners and clients with some of the key contract methods available for the execution of water and wastewater projects in Iran, such as trilateral, EPC, quadripartite, cooperative, bilateral, DBOT, and BOT. The risks associated with the implementation of some of these contract methods in projects were highlighted in the article. In any building or infrastructure project, the way the project is procured has always been a problematic area for the client or the project team. Hence, through the mapping of criteria and sub-criteria to the optimal contract method (highest weighted contract option), the study can guide developers and top management of such project firms or companies. In this, supposing that a client intends to emphasize the 'management and organizational' criteria and the 'economic' criteria; with the decision (selection) model developed, a bilateral contract option is the best option for such a project.

Moreover, the study provided guidelines to clients, project team members, and other practitioners on how each key sub-criterion can influence what contract methods should be adopted. For example, a water and wastewater project developer should consider criteria such as design specifications and increased financing as key to investment decisions. Then, a trilateral contract method will be best suited for water and wastewater projects. More so, for developers that regard the payment method and qualification requirements for contractors as a key variable for investment, a cooperative contract method will best suit the project. Additionally, the study emphasizes the importance of managerial and organizational strategies for the success of a water and wastewater project in Iran. Other important criteria are related to economic and technical factors. Hence, key stakeholders must take into account the variables related to these factors as they significantly determine the performance or success of the project.

Theoretical implications. The analysis of the selected contracting options using the fuzzy analytic hierarchy process based on criteria and sub-criteria provides stakeholders with a list of preferred contract options for their water and wastewater projects in Iran and could be applicable in other developing countries. Prior to this study, water and wastewater projects in Iran often used the trilateral approach to contract. However, based on the study, analysis of the bilateral contract methods was considered the best option for water and wastewater projects in Iran. The study also provided insights into the key factors that contribute to the choice of various contractual approaches in the procurement of water and wastewater projects in Iran. 


\section{Conclusions}

The implementation method is vital to the success of large-scale projects, and the selection of the appropriate contract method is one of the key decisions to make. Using the wrong process to select the implementation system and inadequate contract methods can have adverse effects on the project. When the most suitable contract type is selected, projects can achieve high levels of gain and income. On the contrary, poor decisions regarding the type of contract can result in financial losses and the loss of irreplaceable opportunities at the national level.

The current study prioritized contract methods to help project decision-makers select the best contract methods for water and wastewater projects. First, a list of factors was identified that affect the proper selection of contracts for water and wastewater projects, through a content analysis of the existing literature. In addition, a Delphi questionnaire, based on the identified factors, was developed and distributed among the invited experts. Several validity and reliability tests help to consolidate the factors into 18 criteria, which were classified into five different groups. The FAHP method was used to prioritize the contract methods used in Iranian water and wastewater projects according to 18 criteria, as well as the contract options. Pairwise comparison questionnaires were distributed among experts. The results showed that bilateral, public-private cooperative, trilateral, and quadripartite contract methods (in ascending order) were the best methods for water and wastewater projects in Iran.

The weighting calculation process of the FAHP method helped reduce or eliminate the subjectivity of the data collated through the pairwise comparison questionnaire. The findings of this study will further support and guide the decision of clients and key stakeholders on selecting the appropriate contractual options for their water and wastewater industry in Iran. Although the study is limited by the data obtained in Iran, the findings of the study can be extrapolated for adoption in other countries. The study also outlined the theoretical and practical contributions of the research findings. In addition, the key criteria developed in this study can be implemented for similar projects in Iran and other developing countries.

Meanwhile, the selection of the right contracting methods for large-scale water and wastewater projects depends on factors that can also be context-specific. Hence, it is recommended for future studies to examine the effects of the factors (criteria and subcriteria) in different countries and regions, as well as other sectors of the economy. Another future research direction is to expand the spectrum of available contract types, that is, to identify more contract methods applicable in other contexts (countries or regions) to allow greater generalizability of the results beyond the current scope of this study. Energybased methods and integrated delivery contract methods are possible topics for further studies. The results of the current study on the preferred and common contract methods suitable for the water and wastewater industry can be used to provide a framework for contract selection and use in multiple criteria decision-making methods; and thus aid in the successful implementation of these projects.

The focus of the current study is on issues related to the choice of contracting methods for water and wastewater projects. However, the results can help decision making and fill the existing knowledge gap in other sectors such as energy, communications, and transport.

Author Contributions: Conceptualization, H.S. and N.B.; methodology, H.S. and B.A.; formal analysis, H.S. and B.A.; investigation, N.B., H.S. and D.W.M.C.; data curation, H.S. and D.W.M.C.; writing-original draft preparation, H.S. and N.B.; writing-review and editing, T.O.O. and H.S.; visualization, H.S. and T.O.O.; supervision, H.S.; project administration, N.B. All authors have read and agreed to the published version of the manuscript.

Funding: This research received no external funding.

Institutional Review Board Statement: Not applicable.

Informed Consent Statement: Not applicable. 
Data Availability Statement: The data presented in this study are available as a text file on request. Please reach us at h.sarvari@khuisf.ac.ir.

Conflicts of Interest: The authors declare no conflict of interest.

\section{References}

1. McConville, J.R.; Mihelcic, J.R. Adapting life-cycle thinking tools to evaluate project sustainability in international water and sanitation development work. Environ. Eng. Sci. 2007, 24, 937-948. [CrossRef]

2. Jodar-Abellan, A.; López-Ortiz, M.I.; Melgarejo-Moreno, J. Wastewater treatment and water reuse in Spain. Current Situation and Perspectives. Water 2019, 11, 1551. [CrossRef]

3. Abdel-Basset, M.; Atef, A.; Smarandache, F. A Hybrid neutrosophic multiple criteria group decision making approach for project selection. Cogn. Syst. Res. 2019, 57, 216-227. [CrossRef]

4. $\quad$ El-Abidi, K.M.A.; Ofori, G.; Zakaria, S.A.S.; Mannan, M.A.; Abas, N.F. Identifying and evaluating critical success factors for industrialized building systems implementation: Malaysia study. Arab. J. Sci. Eng. 2019, 44, 8761-8777. [CrossRef]

5. In't Veld, J.; Peeters, W.A. Keeping large projects under control: The importance of contract type selection. Int. J. Proj. Manag. 1989, 7, 155-162. [CrossRef]

6. Marzouk, M.M.; El Kherbawy, A.A.; Khalifa, M. Factors influencing sub-contractors selection in construction projects. HBRC J. 2013, 9, 150-158. [CrossRef]

7. Valipour, A.; Yahaya, N.; Md Noor, N.; Kildienè, S.; Sarvari, H.; Mardani, A. A fuzzy analytic network process method for risk prioritization in freeway PPP projects: An Iranian case study. J. Civ. Eng. Manag. 2015, 21, 933-947. [CrossRef]

8. Chen, K.-H.; Wang, H.-C.; Han, J.-L.; Liu, W.-Z.; Cheng, H.-Y.; Liang, B.; Wang, A.-J. The application of footprints for assessing the sustainability of wastewater treatment plants: A review. J. Clean. Prod. 2020, 277, 124053. [CrossRef]

9. Díaz-Madroñero, M.; Pérez-Sánchez, M.; Satorre-Aznar, J.R.; Mula, J.; López-Jiménez, P.A. Analysis of a wastewater treatment plant using fuzzy goal programming as a management tool: A case study. J. Clean. Prod. 2018, 180, 20-33. [CrossRef]

10. Llácer-Iglesias, R.M.; López-Jiménez, P.A.; Pérez-Sánchez, M. Energy self-sufficiency aiming for sustainable wastewater systems: Are all options being explored? Sustainability 2021, 13, 5537. [CrossRef]

11. Guerrini, A.; Romano, G.; Ferretti, S.; Fibbi, D.; Daddi, D. A performance measurement tool leading wastewater treatment plants toward economic efficiency and sustainability. Sustainability 2016, 8, 1250. [CrossRef]

12. Furness, M.; Bello-Mendoza, R.; Dassonvalle, J.; Chamy-Maggi, R. Building the 'bio-factory': A bibliometric analysis of circular economies and life cycle sustainability assessment in wastewater treatment. J. Clean. Prod. 2021, 323, 129127. [CrossRef]

13. Gherghel, A.; Teodosiu, C.; Notarnicola, M.; De Gisi, S. Sustainable design of large wastewater treatment plants considering multi-criteria decision analysis and stakeholders' involvement. J. Environ. Manag. 2020, 261, 110158. [CrossRef] [PubMed]

14. Munasinghe-Arachchige, S.P.; Abeysiriwardana-Arachchige, I.S.A.; Delanka-Pedige, H.M.K.; Nirmalakhandan, N. Sewage treatment process refinement and intensification using multi-criteria decision making approach: A case study. J. Water Process Eng. 2020, 37, 101485. [CrossRef]

15. Arasteh, M.A.; Farjami, Y. Supporting sustainable rural groundwater demand management with fuzzy decision analysis: A case study in Iran. Util. Policy 2021, 70, 101215. [CrossRef]

16. Kanchanamala Delanka-Pedige, H.M.; Munasinghe-Arachchige, S.P.; Abeysiriwardana-Arachchige, I.S.A.; Nirmalakhandan, N. Evaluating wastewater treatment infrastructure systems based on UN sustainable development goals and targets. J. Clean. Prod. 2021, 298, 126795. [CrossRef]

17. Ho, J.Y.; Ooi, J.; Wan, Y.K.; Andiappan, V. Synthesis of wastewater treatment process (WWTP) and supplier selection via fuzzy analytic hierarchy process (FAHP). J. Clean. Prod. 2021, 314, 128104. [CrossRef]

18. Camci, A.; Çimen, Ö.; Gül, S. Selection of contract type in construction projects using spherical AHP method. In Progress in Intelligent Decision Science; Allahviranloo, T., Salahshour, S., Arica, N., Eds.; Advances in Intelligent Systems and Computing; Springer International Publishing: Cham, Switzerland, 2021; Volume 1301, pp. 531-547. ISBN 978-3-030-66500-5.

19. Taylan, O.; Kabli, M.; Porcel, C.; Herrera-Viedma, E. Contractor selection for construction projects using consensus tools and big data. Int. J. Fuzzy Syst. 2018, 20, 1267-1281. [CrossRef]

20. Faraji, A.; Rashidi, M.; Khadir, P.; Perera, S. A risk analysis-best worst method based model for selection of the most appropriate contract strategy for onshore drilling projects in the Iranian petroleum industry. Buildings 2021, 11, 97. [CrossRef]

21. Nkuah, M.Y. Progress and performance control of a cost reimbursable construction contract. Cost Eng. 2006, 48, 13-18.

22. Gudienè, N.; Banaitis, A.; Podvezko, V.; Banaitienè, N. Identification and evaluation of the critical success factors for construction projects in Lithuania: AHP approach. J. Civ. Eng. Manag. 2014, 20, 350-359. [CrossRef]

23. Aznar, B.; Pellicer, E.; Davis, S.; Ballesteros-Pérez, P. Factors affecting contractor's bidding success for international infrastructure projects in Australia. J. Civ. Eng. Manag. 2017, 23, 880-889. [CrossRef]

24. Budayan, C.; Okudan, O.; Dikmen, I. Identification and prioritization of stage-level KPIs for BOT projects-Evidence from Turkey. Int. J. Manag. Proj. Bus. 2020, 13, 1311-1337. [CrossRef]

25. Sarvari, H.; Chan, D.W.M.; Alaeos, A.K.F.; Olawumi, T.O.; Abdalridah Aldaud, A.A. Critical success factors for managing construction small and medium-sized enterprises in developing countries of Middle East: Evidence from Iranian construction enterprises. J. Build. Eng. 2021, 43, 103152. [CrossRef] 
26. Marović, I.; Perić, M.; Hanak, T. A multi-criteria decision support concept for selecting the optimal contractor. Appl. Sci. 2021, 11, 1660. [CrossRef]

27. Oyatoye, E.O.; Odulana, A.A. A prototype AHP system for contractor selection decision. In Applications and Theory of Analytic Hierarchy Process_Decision Making for Strategic Decisions; De Felice, F., Saaty, T.L., Petrillo, A., Eds.; InTechOpen: London, UK, 2016; ISBN 978-953-51-2560-0.

28. Culp, G. Alternative project delivery methods for water and wastewater projects: Do they save time and money? Leadersh. Manag. Eng. 2011, 11, 231-240. [CrossRef]

29. Godfrey, S.; Asmare, G.; Gossa, T.; Paba, M. Fuzzy logic analysis of the build, capacity build and transfer (B-CB-T) modality for urban water supply service delivery in Ethiopia. Water 2019, 11, 979. [CrossRef]

30. Roustaei, M. Investigating the contracts and proposing better contract types for urban wastewater projects with time and cost reduction and quality improvement approach. In Proceedings of the 2nd Iranian Civil Engineering and Architecture with Emphasis on Entrepreneurship in Construction Industry, Tehran, Iran, 24 June 2018. (In Persian)

31. Mahdavi, A.M.; Heydar, D.N.H.; Iskandari, M.M.; Akbari, R. Financing of design and construction contracts in water and wastewater network. In Proceedings of the First Iranian Conference of Industrial Engineering and Systems, Tehran, Iran, 19-20 December 2012. (In Persian)

32. Merati, S.; Nili, A.M. Criteria for selecting contractors in water and wastewater projects. In Proceedings of the International Conference of Management and Economy in 21st Century, Tehran, Iran, 2 March 2016. (In Persian)

33. Sajedi, S.F.; Hamzeh, P.M. Identification and risk assessment in trilateral contracts for wastewater projects in city of Ahwaz. Q. J. Res. Trends Civ. Archit. Eng. 2017, 7, 97-111. (In Persian)

34. Rezaei, N.A.; Amirsardari, B.; Mohajer, B.M.; Molavi, F. Selection of different contract methods using multivariable decisionmaking techniques. Case study: Urban water and wastewater company of Mashhad. In Proceedings of the 13th International Conference of Project Management, Industrial Research Group, Tehran, Iran, 28-29 January 2018. (In Persian)

35. Olawumi, T.O.; Chan, D.W.M. Identifying and prioritizing the benefits of integrating BIM and sustainability practices in construction projects: A Delphi survey of international experts. Sustain. Cities Soc. 2018, 40, 16-27. [CrossRef]

36. Olawumi, T.O.; Chan, D.W.M.; Wong, J.K.W.; Chan, A.P.C. Barriers to the integration of BIM and sustainability practices in construction projects: A Delphi Survey of International Experts. J. Build. Eng. 2018, 20, 60-71. [CrossRef]

37. Olawumi, T.O.; Chan, D.W.M. Critical success factors for implementing building information modeling and sustainability practices in construction projects: A Delphi survey. Sustain. Dev. 2019, 27, 587-602. [CrossRef]

38. Amiri, A.; Mohseni, F. Investigating the advantages of EPC and its role on water and wastewater projects. In Proceedings of the Iranian Water and Wastewater Science and Engineering Conference, Kerman, Iran, 26-27 February 2013. (In Persian)

39. Abbaszedeh, A.; Parchami, J.M.; Raghihi, A.H. Investigation of content and face validity and reliability of sociocultural attitude towards appearance questionnaire-3 (SATAQ-3) among female adolescents. Iran. J. Psychiatry 2017, 28, 15-20. (In Persian) [CrossRef]

40. Fakhari, M. The management system of planning process and project control for privatization of water and wastewater commissioning. In Proceedings of the 1st National Conference of Water and Wastewater Management, Tehran, Iran, 21-23 February 2006. (In Persian)

41. Downe-Wamboldt, B. Content analysis: Method, applications, and issues. Health Care Women Int. 1992, 13, 313-321. [CrossRef] [PubMed]

42. White, M.D.; Marsh, E.E. Content analysis: A flexible methodology. Libr. Trends 2006, 55, 22-45. [CrossRef]

43. Hasson, F.; Keeney, S.; McKenna, H. Research guidelines for the Delphi survey technique: Delphi survey technique. J. Adv. Nurs. 2000, 32, 1008-1015. [CrossRef] [PubMed]

44. Sarvari, H.; Chan, D.W.M.; Banaitiene, N.; Noor, N.M.; Beer, M. Barriers to development of private sector investment in water and sewage industry. Built Environ. Proj. Asset Manag. 2021, 11, 52-70. [CrossRef]

45. Lovie-Kitchin, J.E. Validity and reliability of visual acuity measurements. Ophthalmic Physiol. Opt. 1988, 8, 363-370. [CrossRef] [PubMed]

46. Ayre, C.; Scally, A.J. Critical values for Lawshe's content validity ratio: Revisiting the original methods of calculation. Meas. Eval. Couns. Dev. 2014, 47, 79-86. [CrossRef]

47. Lawshe, C.H. A quantitative approach to content validity. Pers. Psychol. 1975, 28, 563-575. [CrossRef]

48. Yudiana, Y.; Hidayat, Y.; Hambali, B.; Slamat, S. Content validity estimation of assessment instrument based on volleyball information system of volleyball learning: Field research. IOP Conf. Ser. Mater. Sci. Eng. 2017, 180, 012230. [CrossRef]

49. Ikhsanudin; Subali, B. Content validity analysis of first semester formative test on biology subject for senior high school. J. Phys. Conf. Ser. 2018, 1097, 012039. [CrossRef]

50. Shirali, G.; Shekari, M.; Angali, K.A. Assessing reliability and validity of an instrument for measuring resilience safety culture in sociotechnical systems. Saf. Health Work 2018, 9, 296-307. [CrossRef] [PubMed]

51. Waltz, C.F.; Bausell, R.B. Nursing Research: Design, Statistics, and Computer Analysis; F.A. Davis Co.: Philadelphia, PA, USA, 1981; ISBN 978-0-8036-9040-0.

52. Fadavi-Ghaffari, M.; Azad, A.; Shariatzadeh, H.; Taghizadeh, G.; Aminizadeh, S. Translation, cultural adaptation, face and content validity of the Persian version "Patient-Rated Wrist Evaluation" (PRWE-Persian) questionnaire. J. Mod. Rehabil. 2017, 11, 51. [CrossRef] 
53. Pezeshki, M.Z.; Shadman, A.; Alizadeh, M.; Hakimi, S.; Heidari, F. Validity and reliability of the questionnaire for assessing women's reproductive history in AZAR cohort study. J. Caring Sci. 2017, 6, 183-186. [CrossRef] [PubMed]

54. Taber, K.S. The use of Cronbach's alpha when developing and reporting research instruments in science education. Res. Sci. Educ. 2018, 48, 1273-1296. [CrossRef]

55. Field, A.P. Discovering Statistics Using SPSS: And Sex, Drugs and Rock " $n$ " Roll, 3rd ed.; SAGE Publications: Los Angeles, CA, USA, 2009; ISBN 978-1-84787-906-6.

56. Olatunji, S.O.; Olawumi, T.O.; Aje, I.O. Rethinking partnering among quantity-surveying firms in Nigeria. J. Constr. Eng. Manag. 2017, 143, 05017018. [CrossRef]

57. Olawumi, T.O.; Chan, D.W.M. Key drivers for smart and sustainable practices in the built environment. Eng. Constr. Archit. Manag. 2020, 27, 1257-1281. [CrossRef]

58. Gumus, A.T. Evaluation of hazardous waste transportation firms by using a two step fuzzy-AHP and TOPSIS methodology. Expert Syst. Appl. 2009, 36, 4067-4074. [CrossRef]

59. Wang, Y.-M.; Chin, K.-S. Fuzzy analytic hierarchy process: A logarithmic fuzzy preference programming methodology. Int. J. Approx. Reason. 2011, 52, 541-553. [CrossRef]

60. Fedrizzi, M.; Krejčí, J. A Note on the paper "Fuzzy analytic hierarchy process: Fallacy of the popular methods". Int. J. Uncertain. Fuzziness Knowl.-Based Syst. 2015, 23, 965-970. [CrossRef]

61. Sabahi, F. Bimodal fuzzy analytic hierarchy process (BFAHP) for coronary heart disease risk assessment. J. Biomed. Inform. 2018, 83, 204-216. [CrossRef]

62. Gogus, O.; Boucher, T.O. Strong transitivity, rationality and weak monotonicity in fuzzy pairwise comparisons. Fuzzy Sets Syst. 1998, 94, 133-144. [CrossRef]

63. Deng, H. Multicriteria analysis with fuzzy pairwise comparison. Int. J. Approx. Reason. 1999, 21, 215-231. [CrossRef]

64. Chiang, T.-Y. Real estate developer's product positioning: AHP-utility-based model. Int. J. Strateg. Prop. Manag. 2019, 23, 317-327. [CrossRef]

65. Ahmed, F.; Kilic, K. Fuzzy analytic hierarchy process: A performance analysis of various algorithms. Fuzzy Sets Syst. 2019, 362, 110-128. [CrossRef]

66. Yuan, J.; Li, W.; Xia, B.; Chen, Y.; Skibniewski, M.J. Operation performance measurement of public rental housing delivery by PPPS with Fuzzy-AHP comprehensive evaluation. Int. J. Strateg. Prop. Manag. 2019, 23, 328-353. [CrossRef]

67. Thengane, S.K. Assessment of different technologies for managing yard waste using analytic hierarchy process. Process Integr. Optim. Sustain. 2019, 3, 255-272. [CrossRef] 